\title{
Applying Extended DMAIC methodology to optimize weakly structured business processes ${ }^{1}$
}

\author{
Alexander I. Gromov \\ Professor, Head of Department of Modeling and Optimization of Business Processes \\ National Research University Higher School of Economics \\ Address: 20, Myasnitskaya Street, Moscow, 101000, Russian Federation \\ E-mail:agromov@hse.ru
}

\section{Yulia A. Bilinkis}

Lecturer, Department of Modeling and Optimization of Business Processes National Research University Higher School of Economics Address: 20, Myasnitskaya Street, Moscow, 101000, Russian Federation E-mail:ybilinkis@hse.ru

\section{Nikolay S. Kazantsev}

Lecturer, Department of Modeling and Optimization of Business Processes National Research University Higher School of Economics Address: 20, Myasnitskaya Street, Moscow, 101000, Russian Federation E-mail: nkazantsev@hse.ru

\section{Anastasia G. Zueva}

Lecturer, Department of Modeling and Optimization of Business Processes National Research University Higher School of Economics

Address: 20, Myasnitskaya Street, Moscow, 101000, Russian Federation

E-mail: zueva_ag@mail.ru

\begin{abstract}
The paper is focused on DMAIC methodology, which is currently widely used in projects to optimize routine business processes by implementing 6 Sigma methodologies. The article analyzes the applicability of DMAIC methodology to weakly structured non-linear business processes characterized by uncertainty of the input, output and variability of process instances, primarily dependent on content and user behavior. First, it describes the main steps of the methodology: Define, Measure, Analyze, Improve and Control. These steps are used for a routine documentation approval process. Routine process is regulated and has few exceptions; its instances rarely differ from each other. Standard statistical methods can be used to analyze it, such as control charts. Second, the paper shows approaches to the definition of weakly structured processes with the use of the information field and subject-oriented interaction to achieve the goal. Third, tools and techniques that extend the DMAIC methodology for weakly structured process are proposed using the example of ad-hoc weakly structured operational risk management processes. The main differences were identified in the Define, Measure and Analyze steps. These recommendations can be used in projects to optimize weakly structured processes.
\end{abstract}

Key words: business process, DMAIC, business process optimization, weakly structured business processes.

Citation: Gromov A.I., Bilinkis Yu.A., Kazantsev N.S., Zueva A.G. (2016) Applying Extended DMAIC methodology to optimize weakly structured business processes. Business Informatics, no. 3 (37), pp. 72-79. DOI: $10.17323 / 1998-0663.2016 .3 .72 .79$.

\footnotetext{
${ }^{1}$ The article was prepared within the framework of the Academic Fund Program at the National Research University Higher School of Economics (HSE) in 2016 (grant No. 116-02-0005) and supported within the framework of a subsidy granted to the HSE by the Government of the Russian Federation for the implementation of the Global Competitiveness Program.
} 


\section{Introduction}

$\mathrm{T}$ The methodology of non-linear weakly structured business processes and the principles of their functioning are being developed by scientific and business communities. This is due to the changes in business models of quaternary sector of economy towards an individual approach to the client, intellectualization of the decision-making processes based on the expert assessments and the use of large data, increasing the flexibility and speed of service. A characteristic feature of weakly structured processes is the uncertainty of the input, output and variability of process instances. A high level description of such processes may be stable, but the detailed problems of process instances during their execution are fuzzy and are difficult to replicate, since they are primarily dependent on content and user behavior. Thus, it is almost impossible to create a detailed regulation of the process at the modeling and process automation step and make a decision about all participants in the process and their actions. Typical examples are the processes to produce and provide intellectual services, which are often prevalent in such sectors as the vocational education, science and high technology, information and communication markets, production innovation, intellectual services (consulting, analysis, information brokerage, marketing and banking services, etc.).

This paper proposes an integrated approach to improving management efficiency based on new methods of analysis and monitoring, taking into account the specific characteristics of weakly structured processes which impose restrictions on the use of traditional methods. By effective management we mean reaching the goal for each business process separately while minimizing costs for achievement under the influence of managerial decisions.

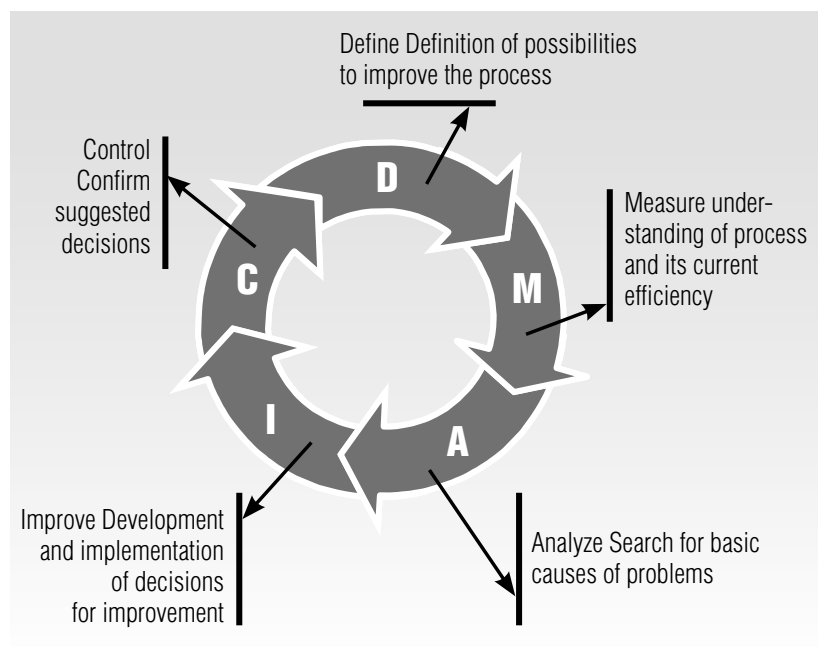

Fig. 1. DMAIC methodology
The objective of this study is to optimize the DMAIC methodology for weakly structured business processes. Consultants often use DMAIC methodology, developed under 6 Sigma concepts as part of a project to improve the operational efficiency of routine business processes (Figure 1).

Traditionally, 6 Sigma is used to set up regular business processes to reduce all types of defects and losses in the production of standardized products and services. As a part of the traditional definition by routine business process we mean a set of interrelated consistent actions having inputs and outputs, covering the different enterprise entities and subordinate to a specific purpose, such as the definition of M. Hammer and T. Davenport. The effectiveness of a structured process is easy to measure taking into account the fact that the set of works is always predetermined and structured. Thus, evaluating the performance of all the components, we can reach a conclusion about the effectiveness of the entire process. As indicators for monitoring, process parameters can be selected which are relevant objectives of each function/sub-process with a certain periodicity of collection; by using them, the organization receives a well-balanced system of indicators of symptoms of problems. DMAIC involves a gradual transition from the general understanding of the most effective solutions to the problems with minimal cost and in the shortest time.

This paper proposes some new tools that can be used at each step of this methodology for weakly structured business processes. Next, we will discuss the application of DMAIC methodology for regulated business process and weakly structured business process.

\section{The first step for routine business processes: Define}

The requirements of customers and business are defined at this step: the Voice of Customers and the Voice of Business, the optimization goal is set, the expert working group is determined, the project charter is defined. This step aims to define clear boundaries of the optimized process and its key participants. It is very important to create a functioning working group at this stage. Such group will include the direct executors of the process. It is necessary to create a detailed process map for uniquely detailed understanding of its functioning.

It is important to identify defects in the process of understanding the consumer ("voice of the customer"). Consumers are not obliged to express their wishes for the process in a clear format; the task of the working group 
is to convert them into quantitative indicators that are crucial for quality and to understand the big picture for the right direction for optimization.

Consider a structured description of the business process in terms of subject-oriented approach on the example of a higher-level process of "Quality Management". For the structured business process "Quality Management," you can highlight the following problem ("voice of the customer"): "the annual program to improve the quality management system (QMS) is developed with delays". "Voice of the customer" can be converted to the "voice of the process" - indicators that correspond to the objectives of each function / sub-process with a certain periodicity of collection by which the organization will receive a well-balanced system of indicators of problems. For the afore-mentioned "voice of the process", the problem can be formulated as follows: "preparation of regulatory documents should not exceed three working days after the request is sent". The question arises: how to achieve the goal of " 3 business days"?

\section{The second step for routine business processes: Measure}

TQM postulates that a product or service of poor quality is the result of unpredictable variability of the process or the input parameter at the beginning of the process, or during the execution of the process. They say that the process is statistically controlled when the only source of variation is a natural cause - variability originating from numerous sources and inherent in the process. Natural changes behave as a system of random factors with constant parameters. While all process instances differ, they form a certain pattern as a group; it can be described as a distribution. The reduction of this variation requires management solutions and investment capital (for example, to purchase new equipment). If this is a normal distribution, it is characterized by two parameters: the mean and standard deviation. It is impossible to measure the mean and standard deviation in practice, since this would require the measurement of all possible instances of the process. Instead they use a number of measurements taken over time by measuring the sample mean and sample variance, respectively. Until the distributions of these parameters are within predetermined limits, the process is statistically controlled and natural variations are allowable. If they come out of the specified parameters, this is due to non-random changes that are not inherited by the process. Reduction of variation requires a special analysis of its causes (Figure 2).

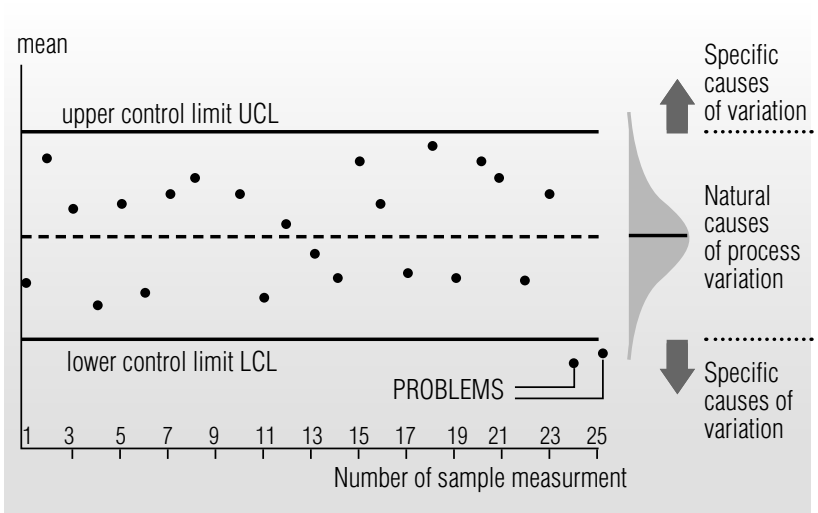

Fig. 2. Natural and special causes of variation

For example, the above process is necessary to consistently measure the time of preparation of regulatory documents for the construction of control charts to obtain information on the number of defects and their dynamics. With the reference sigma level, we conclude the process of statistical control, with levels of specifications a process according to customer requirements.

The measurement system at this point is to collect data for the Analyze step.

\section{The third step for routine business processes: Analyze}

The objective of the quality control system is to supply the statistical signal of the presence of non-random causes. Such a signal can accelerate the adoption of measures aimed at eliminating the causes of non-random. The particular variation can be caused by:

Specific events in the process: the actions of men, change settings, etc.

$\checkmark$ Factors of process groups: in shifts, operators, etc.

$\downarrow$ External factor categories: suppliers, environmental conditions, etc.

For example, in the framework of an expert study for the process we can find that one of the hypotheses about the reason for the delay in submission of documents is the lack of necessary data. After the systematization of the existing information about this issue, it is possible to carry out a production experiment to prove or disprove it.

Relying on all the causes of the problems that can be allocated, it is possible to build a mathematical model of the process $Y=f(x)$. Knowing the model, it is possible to predict the result quite reliably and to adjust the settings according to the factors based on the calculations. Thus, we can move from reactive to proactive process management (Figure 3). 


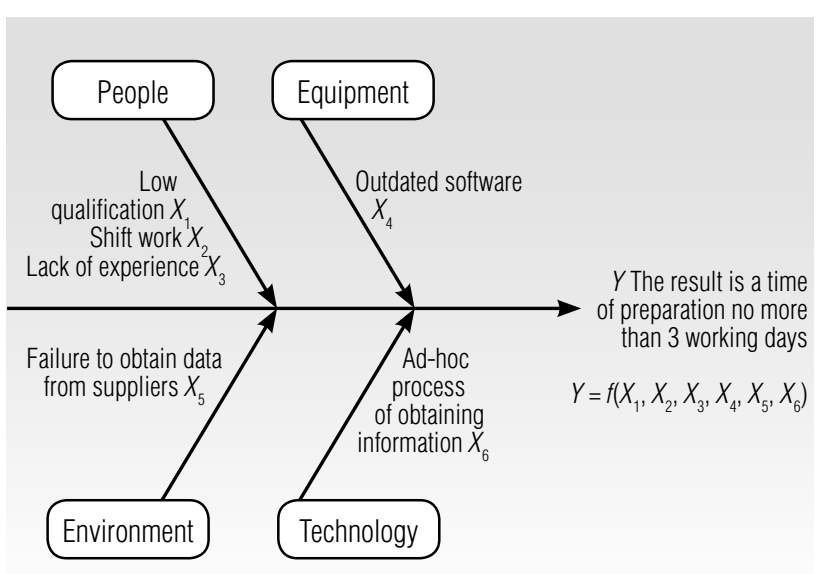

Fig. 3. Process as a transformation function. The result of the process depends on factors (causes)

Thus, the preparation of the documentation depends on the combination of the six main factors and individual measurement systems need to be built for each of them in order to ensure active management of the entire system. To do this, you must determine the exact value of input factors $x_{1}, x_{2}, x_{3}, x_{4}, x_{5}, x_{6}$, providing the desired result value $Y$, as well as the tolerance input parameters $\Delta x_{1}, \Delta x_{2}, \Delta x_{3}, \Delta x_{4}, \Delta x_{5}, \Delta x_{6}$, providing tolerance result $\Delta Y$.

\section{The fourth step for routine business processes: Improve}

At this stage, process optimization solutions are found to meet the performance planned values $x_{1}, x_{2}, x_{3}, x_{4}$, $x_{5}, x_{6}$, and then use any measures to achieve its results. This often entails a change of technological modes, upgrading processes or areas, organizational work with the team.

In this step, solutions for improving the process using the identified factors based on the results of the previous step are developed and implemented. To do this, it is necessary:

$\diamond$ to select the solution by the preliminary expert evaluation of cost and effectiveness;

$\diamond$ to conduct experiments, to evaluate the effectiveness of solutions in the pilot launch (PDCA Cycle) of solutions to remove the problems;

$\diamond$ to evaluate the results of the pilot launch;

$\diamond$ to plan the full deployment of the new process.

For example, for our process it is necessary to create a single distributed data mart with the information about regulatory documents. After this upgrade, it is necessary to stabilize the process parameters on the first pilot solution and then when replicating.

\section{The fifth step for routine business processes: Control}

During this step, the developed solutions are extended and fixed. To do this, it is necessary to design the system for controlling and monitoring the solutions developed, the plan for monitoring the implementation of changes and achieving KPI is to be set, process documentation is updated. The plan for engaging members in the new process is to be set as well, and the final step is to transfer the new process to the Process Owner. All this is necessary for successful replication of the improved process.

\section{Weakly structured processes}

This work is not always being done consistently and with pre-defined structure. According to the modern approach, it becomes clear that the process can contain both structured work and ad-hoc works, often unique challenges. Such processes can be called nonlinear intelligent, dynamic and contextual in nature. The characteristic features of such processes are listed below [1]:

- customization to a specific consumer, i.e. intellectual service cannot be a typical (it is unique): provided to one client, it cannot be intact or provided to another customer, since it requires data recollection, analysis and information presentation;

- association of consumption process with the production process through constant interaction with consumers and fast response to demand;

- a large number of sub-processes and tasks and interdependencies between tasks.

- each process task depends on other tasks, which leads to a large amount of feedback, the availability of information on the previous and subsequent process steps;

- the use of explicit and implicit knowledge of experts. The behavior of process performers depends on their knowledge, which is a constantly changing mix of experience, values and incoming information;

- depending on the context, knowledge of the subject area is used to perform the process, it includes tasks, documents, experts, and other indicators. The performed process is not limited to the orchestration of Web services and the sequence of tasks, but also involves obtaining all relevant information about the process;

- focusing on the executer, collaboration and decisionmaking requires the development and selection of integrated solutions among the fastest possible alternatives 
to achieve some certain goals. Responsibility of employees increases demands on their skills and competence;

- distributed processes. Process participants are not only employees of the company; the successful outcome of the process is highly dependent on corporate communications due to valuable ideas coming from the external environment and outflows of ideas from the company which have no value for it.

For example, in the process of responding to operational risks it can be shown that in the event of an unplanned incident the risk management process will be a search for solutions among community employees, experts in the field. In terms of subject-oriented approach, the subject (member of the process) is the starting point to describe a situation or event. Subjects synchronize their activity through messaging to switch between their functional states. As part of the weakly structured process execution, subjects generate content. With a proper assessment of that content, it is possible to distinguish the purpose of the process and its semantic environment.

The idea of presenting processes with the help of unstructured information has been described by several authors. The formation of an automation system model of an enterprise as a multilayer taxonomy has been made in work [2], where the company is regarded as a "scale significant collection of various information entities", which can be classified by created taxonomy. In work [2], structural units of the enterprise are root taxa, keywords are the end ones and define a business process - operations. Defining ontology and formal models of business processes of a telecommunication enterprise are described in detail in the paper [3], where the taxonomy of business processes was described based on the reference ontology. Then the ontology was created based on real business processes of the organization after their comparison and analysis. Both ontologies have been formed on the basis of a common glossary of terms (Figure 4).

The subject "Initiator" sends a message "The application for the community creation" to subject "Agent" (this is not a human, but an element of an IT system). The "Agent", who has staff profiles, sends two messages with his recommendations on potential participants and their profiles to the "Initiator". Having examined the recommendations and profiles of candidates, the "Initiator" sends an invitation to potential participants and, after receiving consent, creates a new community for problem solving. The formal establishment and registration of the community is operated by the "Agent". A potential investor becomes a participant in the innovation process.

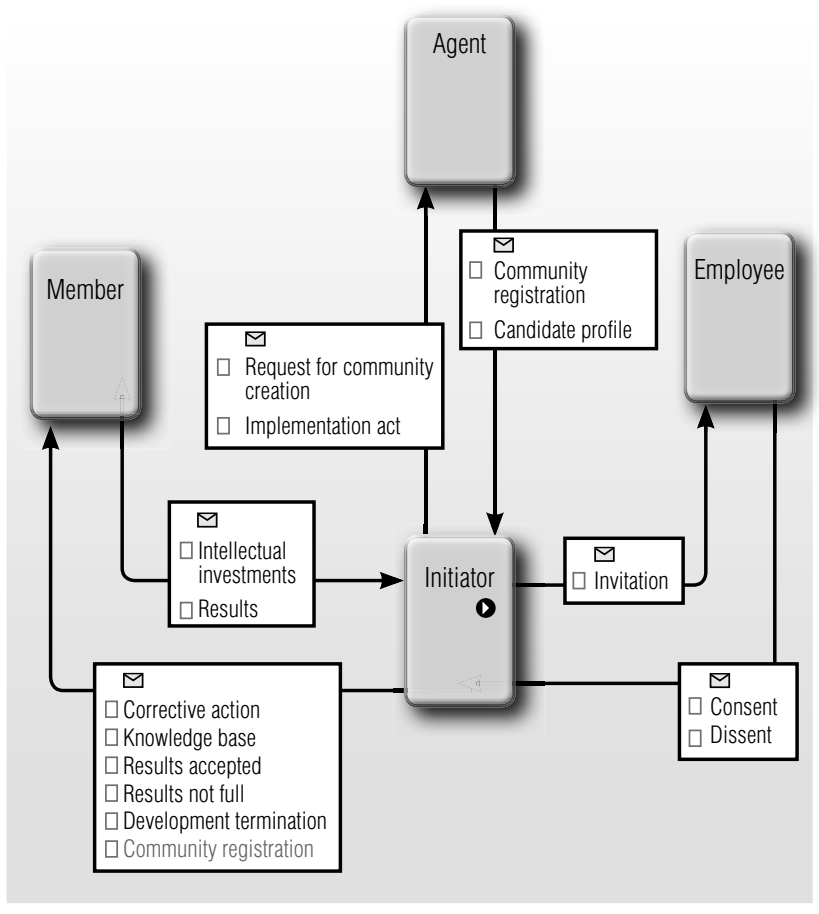

Fig. 4. A weakly structured process

Within the scope of the study, the process is determined as 1) the information field, which is a set of messages which are exchanged between the participants during the process to achieve a certain objective; 2) subjects (participants of the project) - implicit expert knowledge carriers. The information field is given by the characterizing topics of the text information, which in turn are defined by terms. A topic is not just a set of terms (keywords); it is not random, but stable characteristics of a set of semantically related terms characterizing the process. This was confirmed in the works [4-7].

\section{DMAIC for weakly structured business processes}

Here are the distinguishing features of weakly structured processes affecting the instruments of DMAIC methodology.

1. On the Define and Measure steps, it is very difficult to construct a process map. The weakly structured process itself can be defined as a set of concerted efforts of the interacting participants - information and knowledge holders. This is obvious if we consider the activities of the company as a result of the functioning of the socio-techno-economic system. Thus, the activities under process are process-oriented search for the required procedural decisions in the system of distributed information and knowledge. The efficiency of the entire process depends on the efficiency of search management. 
2. The choice of indicators for weakly structured processes on the Measure step is not a trivial task. Very often it's possible to use only delayed parameters of the process result, but in case they are used it is difficult to respond quickly to problems emerging during the process implementation. The advantage of leading indicators is that they have the prognosticating nature and allow the organization to adjust its actions quickly on the basis of comparison of the actual indicators values with planned values. For weakly structured processes, it is recommended to use indicators related with the process information field, as elements of a leading indicators subset.

3. At the Measure step, the measurement is performed; it is gathered data on the problem $(Y)$ and possible root causes $\left(X_{n}\right): Y=f\left(x_{1}, x_{2}, \ldots, x_{k}\right)$, where $Y$ is the result of a process, $X_{n}$ - inputs and internal factors of the process. The purpose for the weakly structured process is clearer than the way of achieving it; therefore, the choice of the way will be determined in the course of achieving the goal based on the information and would not be planned in advance, so it cannot be fixed in a low-level regulations or process model. Defining weakly structured processes can be impractical because of the measurement of the same parameter for different instances of the same business process; different values will be received faster due to the following reasons:

the business process is characterized by complex logical and temporal structure, so a copy of it can be developed in different ways depending on numerous conditions;

objects incoming to the business process for different instances can have different values of the same parameters and that significantly affects the development of the whole business process;

- subject actions of the business process can be changed under the influence of external and internal environments;

४ some activities within the business process related to decision-making can have an informal, unregulated character.
4. The control maps method described above can be used only for structured processes. Control maps cannot be applied if the inputs are not homogeneous, the process is not regular, the output parameters are unique, i.e. for weakly structured processes there must be developed a new approach which enables us:

$\diamond$ to define the nonrandom variation causes of the weakly structured process in order to respond to the situation when process parameters go beyond the scope and thus to identify problems before the client meets them.

$\diamond$ to reduce the variability of the process, to improve the product or process input parameters, thus reducing the likelihood of unpredictable variations impacting the process and leading to problems.

\section{Conclusion}

This paper proposes an integrated approach to improve the efficiency of managing semi-structured processes based on analysis of the applicability of traditional business processes management and the definition of new methods of measurement and analysis allowing for semi-processes. Optimization of DMAIC methodology for weakly structured processes:

- under the Define phase, we provide a method for describing weakly structured process with a data field and a subject-oriented approach;

- under the Measure phase, the identification of nonrandom deviations (bottlenecks, errors) should be done through an analysis of weakly structured information about the process for tracking leading indicators;

- under the Analyze phase, to identify root causes of problems weakly structured process based on an analysis of the information field it is necessary to use the knowledge of experts.

- under Improve and Control phases, to manage semistructured processes for suggested use of standard methodology DMAIC methods proven to be effective.

In general, the results of this work suggest the applicability of DMAIC methodology to weakly structured process management.

\section{References}

1. Dulesov A.S., Khrustalev V.I. (2012) Opredelenie entropii kak mery informatsii pri sopostavlenii prognoznykh i fakticheskikh pokazateley predpriyatiya [Definition of entropy as a measure of information by comparing predicted and actual performance of an enterprise]. Modern Problems of Science and Education, no. 1. Available at: http://www.science-education.ru/ru/article/view?id=5290 (accessed 01 March 2016) (in Russian).

2. Konev K.A. (2013) Kontseptual'naya model' avtomatizatsii predpriyatiya aviatsionnogo priborostroeniya na osnove aktualiziruemoy mnogosloynoy taksonomii [Conceptual model of automation of an aviation instrument making enterprise based on the multi-layer continuously updated taxonomy]. Herald of USATU, vol. 17, no. 5 (58), pp. 70-77 (in Russian).

3. Chistov D.A., Kamaev V.A., Nabokov M.V. (2011) Ontologicheskiy reinzhiniring biznes-protsessov operatora svyazi [Ontological reengineering business processes for a communications operator]. Large-Scale Systems Control, no. 33, pp. 5-20 (in Russian). 
4. Zelenkov Yu.A. (2013) Ob izmerenii effektivnosti biznes-protsessov i podderzhivayushchikh ikh informatsionnykh sistem [On the measurement of the effectiveness of business processes and their supporting information systems]. Large-Scale Systems Control, no. 41, pp. 146-161 (in Russian).

5. Jung J.-Y. (2008) Measuring entropy in business process models. Proceedings of the 3rd International Conference on Innovative Computing Information and Control (ICICIC'08), 18-20 June 2008, Dalian, China. P. 1007-1010.

6. Newman D., Karimi S., Cavedon L. (2009) External evaluation of topic models. Proceedings of the 14th Australasian Document Computing Symposium, 4 December 2009, Sydney, Australia. P. 11-18.

7. Streibel O. Mining trends in texts on the web. Proceedings of the Doctoral Consortium of the 3rd Future Internet Symposium 2010, 23-24 September 2010, Berlin, Germany. P. 80-90.

8. Lopatin V.A. (2008) Sistema upravleniya biznes-protsessami [Control system of business processes]. Management in a Credit Institution, no. 6, pp. 77-99 (in Russian).

9. Keeney R.L., Rife H. (1981) Prinyatie resheniy pri mnogikh kriteriyakh: predpochteniya i zameshcheniya [Decision-making in many criteria: preference and substitution]. Moscow: Radio and Communications (in Russian).

\title{
Применение расширенной методологии DMAIC для оптимизации слабоструктурированных процессов ${ }^{1}$
}

\section{А.И. Громов}

кандидат химических наук, заведующий кафедрой моделирования и оптимизации бизнес-процессов Национальный исследовательский университет «Высшая школа экономики»

Адрес: 101000, г. Москва, ул. Мясницкая, д. 20

E-mail: agromov@hse.ru

\section{Ю.А. Билинкис}

преподаватель кафедры моделирования и оптимизации бизнес-процессов Национальный исследовательский университет «Высшая школа экономики» Адрес: 101000, г. Москва, ул. Мясницкая, д. 20

E-mail:ybilinkis@hse.ru

\section{Н.С. Казанцев}

преподаватель кафедры моделирования и оптимизации бизнес-процессов Национальный исследовательский университет «Высшая школа экономики» Адрес: 101000, г. Москва, ул. Мясницкая, д. 20

E-mail:nkazantsev@hse.ru

\section{А.Г. Зуева}

преподаватель кафедры моделирования и оптимизации бизнес-процессов Национальный исследовательский университет «Высшая школа экономики» Адрес: 101000, г. Москва, ул. Мясницкая, д. 20

E-mail:zueva_ag@mail.ru

\begin{abstract}
Аннотация

\footnotetext{
${ }^{1}$ Статья подготовлена в ходе исследования 116-02-0005 в рамках программы «Научный фонд Национального исследовательского университета «Высшая школа экономики» (НИУ ВШЭ)» в 2016 г., с использованием средств субсидии на государственную поддержку ведущих университетов Российской Федерации в целях повышения их конкурентоспособности среди ведуших мировых научно-образовательных центров, выделенной НИУ ВШЭ.
}

В статье рассмотрена методология DMAIC, которая на данный момент повсеместно используется в проектах оптимизации регламентированных бизнес-процессов, с точки зрения ее применимости к слабоструктурированным нелинейным бизнес-процессам, которые характеризуются неопределенностью входных и выходных данных, а также вариативностью экземпляров процесса, зависимостью от контекста и поведения участников процесса. Во-первых, на примере регламентированного процесса согласования документации описаны основные этапы методологии: Определение (Define), Измерение (Measure), Анализ (Analyze), Улучшение (Improve) и Контроль (Control). Экземпляры регламентированных процессов 
соответствуют предустановленному регламенту и имеют мало исключений. Для их анализа можно использовать стандартные статистические методы, например, контрольные карты. Во-вторых, в статье дается определение слабоструктурированного процесса с помощью понятий информационного поля и субъектно-ориентированного взаимодействия. В-третьих, на примере слабоструктурированного процесса реагирования на операционные риски предложены инструменты и методы, расширяющие методологию DMAIC для оптимизации слабоструктурированного процесса. Основные отличия были обнаружены на этапах Определение (Define), Измерение (Measure) и Анализ (Analyze). Полученные рекомендации могут быть использованы в проектах по оптимизации слабоструктурированных процессов.

Ключевые слова: бизнес-процесс, DMAIC, оптимизация бизнес-процессов, слабоструктурированные бизнеспроцессы.

Цитирование: Gromov A.I., Bilinkis Yu.A., Kazantsev N.S., Zueva A.G. Applying Extended DMAIC methodology to optimize weakly structured business processes // Business Informatics. 2016. No. 3 (37). P. $72-79$.

DOI: $10.17323 / 1998-0663.2016 .3 .72 .79$.

\section{Литература}

1. Дулесов А.С., Хрусталев В.И. Определение энтропии как меры информации при сопоставлении прогнозных и фактических показателей предприятия // Современные проблемы науки и образования. 2012. № 1. [Электронный ресурc]: http://www.scienceeducation.ru/ru/article/view?id=5290 (дата обращения 01.03.2016).

2. Конев К.А. Концептуальная модель автоматизации предприятия авиационного приборостроения на основе актуализируемой многослойной таксономии // Вестник УГАТУ. 2013. Т. 17. № 5 (58). С. 70-77.

3. Чистов Д.А., Камаев В.А., Набока М.В. Онтологический реинжиниринг бизнес-процессов оператора связи // Управление большими системами. 2011. № 33. С. 5-20.

4. Зеленков Ю.А. Об измерении эффективности бизнес-процессов и поддерживающих их информационных систем // Управление большими системами. 2013. № 41. С. 146-161.

5. Jung J.-Y. Measuring entropy in business process models // Proceedings of the 3rd International Conference on Innovative Computing Information and Control (ICICIC' 08), 18-20 June 2008, Dalian, China. P. 1007-1010.

6. Newman D., Karimi S., Cavedon L. External evaluation of topic models // Proceedings of the 14th Australasian Document Computing Symposium, 4 December 2009, Sydney, Australia. P. 11-18.

7. Streibel O. Mining trends in texts on the web // Proceedings of the Doctoral Consortium of the 3rd Future Internet Symposium 2010, 23-24 September 2010, Berlin, Germany. P. 80-90.

8. Лопатин В.А. Система управления бизнес-процессами // Управление в кредитной организации. 2008. № 6. С. 77-99.

9. Кини Р.Л., Райфа Х. Принятие решений при многих критериях: предпочтения и замещения. М: Радио и связь, 1981. 